\title{
Political Aspects of Shari'a Banking Law in Indonesia
}

\author{
Djawahir Hejazziey \\ Lecturer at the Faculty of Sharia and Law \\ UIN Syarif Hidayatullah Jakarta \\ djawahirhejazziey@gmail.com
}

\begin{abstract}
Abstrak
Artikel ini mendiskusikan sejarah berdirinya perbankan syariah di Indonesia. Penulis mengkaji asal usul berdirinya dan berpendapat bahwa, di antara aspekaspek yang mempengaruhi, aspek politik lebih memberikan kontribusi terhadap pembentukan perbankan syariah. Penulis menghadirkan sejumlah bukti tentang bagaimana politik memainkan peran penting dalam keberhasilan pembentukan perbankan syariah. Salah satunya adalah adanya saling ketergantungan antara ekonomi dan politik Islam yang dapat dibaca melalui gagasan Muslim Indonesia ketika membangun bank syariah yang sarat akan muatan politis. Pada awalnya, hubungan antara umat Islam dengan Orde Baru diliputi dengan kecurigaan dan prasangka. Para penguasa Orde Baru di tahun 1970-an masih curiga terhadap gagasan pendirian negara Islam atau realisasi dari Piagam Jakarta. Hingga saat ini, ide tersebut masih diperdebatkan.
\end{abstract}

\begin{abstract}
This article discusses the history of the establishment of Islamic banking in Indonesia. The author examines the derivers of their establishment and argues that, aside other aspects, political aspects give contribution to the establishment of the Islamic banking. He describes a number of evidences of how politics play an important role in the success of their establishment; one of those proofs is the economic and political Islam interdependence which can be read in the idea of Indonesian Muslims on establishing Islamic banks, which is influenced by political content. At the beginning, the relationship between Muslims and the New Order was covered with suspicions and prejudices. The rulers of the New Order in the 1970's were still suspicious of the idea on the establishment of an Islamic state or the realization of the Jakarta Charter. Until recent days, the idea is still debated.
\end{abstract}

Keywords: Islamic banking, politics, shari'a 


\section{Introduction}

When we talk about the politics of Islamic banking law, we may imagine in our minds that the law is a week institution. There is a thought that law is an object of politics, and politics is the subject that gives effect to the law. ${ }^{1}$ This shows that the law is a political product, so that when discussing the politics of law we tend to describe the political influence of the legal or political system on the development of the law to change the political climate that brings order towards better governance. In addition, Indonesia is increasingly growing up in terms of the application of law $^{2}$ and democracy, ${ }^{3}$ law enforcement, ${ }^{4}$ legal equality, human rights, ${ }^{5}$ social equality and so forth.

Bellfroid defines that rechtpolitiek (legal politics) is the process of the formation of ius contitutum (positive law) from ius contituendum (law that would and should be set) to meet changes in social life. Political law is sometimes also associated with public policy which, according to Thomas Dye, is "whatever the government chooses to do or not to do". Besides, Political law is also defined as the development of the law. ${ }^{6}$

\footnotetext{
${ }^{1}$ The law of attraction is the result of various political forces that manifest in the legal product. In this case Satjipto Raharjo said that the law is the instrumentation of the ruling or the political will, so that the legislation is loaded with specific interests, and thus the field of law making the field clash and struggle of interests. Law-making body will reflect the configuration of forces and interests that exist in society. Configuring the strengths and interests in law-making body is important because modern law-making is not just a matter of law formulated by default the following signs juridical, but to make political decisions in advance. Besides the configuration of forces and interests in law-making body, external interventions cannot be ignored in the formation of legislation. The intervention was conducted primarily by groups who have power and strength, socially, politically and economically. See Jazuni, Legislation Islamic Law in Indonesia (Bandung: Citra Aditya Bakti, 2005), first printing, 9.

${ }^{2}$ Sri Wahyuni, "Politik Hukum Islam di Indonesia (Studi terhadap Legislasi Kompilasi Hukum Islam)", Jurnal Mimbar Hukum No. 59 T XIV, al-Hikmah, (2003): 74.

${ }^{3}$ Nurcholis Madjid, "Demokrasi dan Demokratisasi di Indonesia", ed. Elsa Pedi Taher, Demokratisasi Politik, Budaya dan Ekonomi (Jakarta: Paramadina, 1994), cetakan pertama, 203.

${ }^{4}$ Suny Ismail, Sekitar UUPA (Dalam Kitab Agama Dalam Negara Pancasila) (Jakarta: Pustaka Antara, 1990), Cet. 1, 114.

${ }^{5}$ In Indonesia, respect for human rights have been secured by Pancasila and Act of 1945, as a way of life, philosophy and constitutional bases for the Unitary State of Indonesia. Although the embodiment of a new formal material and exist after the issuance of the law No. 39 Year 1999 on Human Rights Court, the law was issued as one series of national plans of action for human rights based on Presidential Decree 129 of 1998. As known, the discharge of the law after violent incidents occurred in Indonesia, especially during the New Order government, such as the Tanjung Priok case, Tim-Tim, clover and so forth. These cases are still in process. There are at least two major obstacles in solving human rights cases in the past, namely technical problems involving procedural and evidentiary legal political constraints that are characterized by the presence of a large force to hamper efforts to settle through the court. Mahfud MD, "Politics of Human Rights Law in Indonesia" (Inauguration Speech in office Professor, Islamic University of Indonesia, Yogyakarta, September 23, 2000).

${ }^{6}$ Sri Wahyuni, 'Politik Hukum Islam di Indonesia (Studi Terhadap Legislasi Kompilasi Hukum Islam (KHI), 74.
}

106 | INDO-ISLAMIKA, Volume 2, Nomor 1, 2012/1433 
Law has a great connection with various aspects of life, namely, State ideology, social, political, economic, legal system and cultural systems, both local and regional, and even global. This synergistic relationship has resulted in the growth of facts that influence the formation of law. When shari'a banking law will be and even has been established, pros and cons among people come to the surface. Some people see it positively, while others consider that it has nothing to do with the implementation of shari'a law. The Partai Damai Sejahtera (Prosperity and Peace Party) faction party spokesman Rosmanita Retna Situmorang, for example, states that "regarding Islamic banking have been regulated in the Law of the Republic of Indonesia No. 10 of 1998. So, a special law needs not to be issued to regulate the activities of Islamic banking. ${ }^{7}$

In the politics of law on shari'a banking, the political elite of Islam has strong bargaining power in the political interaction and large opportunity for the development of Islamic law in the political superstructure. ${ }^{8}$ Conversely, during the Dutch colonial period, the position of Islamic law was much marginalized. Islamic law was seen as the law only when it was recognized in customary law (adatrecht): it was in the third strata of European law and customary law of a foreign Easterner (Arabic, Chinese and Indian). ${ }^{9}$ Indonesia had undergone the process of introduction and the development of foreign legal systems within indigenous law. ${ }^{10}$ Therefore, it is clear that there are many factors involved in the establishment of Islamic law in Indonesia.

At first, the politics of Islamic law in Indonesia, in terms of the development of national law, was influenced by the "receptie" theory developed by Snouck Hurgronje. However, at the end of the reign of the new order, this theory began to diminish in its influence and eventually was presumed dead. During the current reform period there has been proven acceptance of Islamic law (civil and Muamalat) unanimously as positive law. This is evidenced by the inclusion of the Religious of the Judiciary, the abolition of fiat executing the decision of the Religious, no longer an option in the Islamic inheritance laws and the implementation of Islamic economy and the expansion of the authority of the Religious. However, there is political elite that still possesses a phobia towards the implementation of Islamic law. ${ }^{11}$ Political elites have a shallow understanding of religious law, and assume that

${ }^{7}$ Cik Hasan Bisri, “Transformasi Hukum Islam Ke dalam Sistem Hukum Nasional”, Jurnal Mimbar Hukum No. 56 Thn XIII (Jakarta, Al-Hikmah, 2002), 31.

${ }^{8}$ Cik Hasan Bisri, Transformasi Hukum Islam Ke Dalam Sistem Hukum Nasional, 32.

${ }^{9}$ Sri Wahyuni, "Politik Hukum Islam di Indonesia (Studi Terhadap Legislasi Kompilasi Hukum Islam (KHI)."

${ }^{10} \mathrm{http}$ //aanaboodzforlife.com/2010/02/sistem-perbankan-syariah dalam perspektif-politikhukum-indonesia-pada-saat-ini (Diakses pada tanggal, 12 Maret 2010).

${ }^{11}$ Soejono Soekanto, Pokok-Pokok Sosiologi Hukum (Jakarta: Rajawali, 1991), 36. 
the religious affairs are merely individual matter that only regulate human affairs with God.

A legal expert from Austria, Eugen Ehrlich, argued that the influence of law in society has to do with the legal approach to living within the community itself. This means that, "a good law is the law in accordance with the law of people who live in the community." This theory stems from the difference between positive law and the law of the living (living law) in the community. He stated that positive law will only be effective if it is in harmony with the law of people who live in societies, which in terms of anthropology is known as culture patterns. ${ }^{12}$

Eugen Ehrlich advocated for the conduct of legal reform through legislation with the consciousness to pay attention to the fact which is exist in that society. The facts are called "living and just law", which is the "inner order" of the community reflecting the values that live in it. If you want a change of law or to make any law for the law or the Act which will be acceptable and effective in their lives, then one thing worth is the law that lives in that society. ${ }^{13}$ If this does not get attention, then the consequences the law cannot be effective, even it will be challenged (rigid).

\section{Embryo of Islamic Banking Law}

The political struggle for Islamic banking law is partly efforts in the implementation of Islamic law in Indonesia by the Indonesian people, especially Muslims. These efforts have long been formatted through the Jakarta Charter, but they have always failed.

Despite the common or frequent failure of efforts for the formalization of Islamic law, the struggle of Muslims did not stop there, but continued until the Constituent Assembly at its peak in 1959. In the Constituent Assembly, there was a forum where Islamic parties fight for Islam to become the basis of the State, which then means that Islamic law is to be applied not only to Muslims, but also to the entire people of Indonesia. ${ }^{14}$ In the end, this struggle becomes stranded, because the supporting voice of Islam as the basis for the State was still smaller than the votes which rejected it. However, many assumed that Muslims have a huge desire to impose Islamic law in Indonesia.

In the context of contemporary political Islam, although Islam has its own system and style in managing the government, most Islamic countries are more

\footnotetext{
${ }^{12}$ W. Friedman, Legal Theory, 3rd Edition (London: Stevens and Sons Ltd. 1953), 52.

${ }^{13}$ M. Dawam Rahardjo, Introduction to Bank Islam Analisis Fiqih dan Keuangan, by Adiwarman Karim (Jakarta: PT Raja Grafindo Persada, 2006), xiii.

${ }^{14}$ Daud Rasyid, Reformasi Republik Sakit: Peluang dan Tantangan Penerapan Syariat Islam Pasca Kejatuhan Soeharto (Bandung: Syaamil, 2006), Cet. Pertama, 82.
}

108 | INDO-ISLAMIKA, Volume 2, Nomor 1, 2012/1433 
colored by the Western system and its instruments. Why is that? The answer is that the interaction of civilizations between the West and Islam gives effect to a number of Muslim intellectuals to accept the alternative offered by the West in politics, rather than maintain an existing system which has proven its truth and efficacy. ${ }^{15}$

Western countries today are haunted not only by the establishment of the Islamic Caliphate, but also by a state based on Islam as an ideological principle. They exert every effort to obstruct and suppress the Islamic state that has been established because they fear the spread in the formation of a new state based on Islam as an ideological principle.

For that, the West has rejected the concept of Islamic State of interests through which ideas and thoughts expressed by figures of Muslims themselves who have been influenced by western education and ideas. At this level of thought, the West has managed to produce intellectuals who are ready to agree and become spokespersons for the West, and who, whether intentionally or not, will not accept the establishment of an Islamic state for any reason. They are more familiar with Western thought than liberals of the method Qur'an and Hadith. They are Indonesian Intellectuals who have an ease in scrolling through their thinking, because they live in the midst of the Muslim community and many of them hold strategic positions in the government, both as practitioners and academics. West people feel the difficulty, arising from the Western people themselves (orientalist); ${ }^{16}$ because they believe (and will certainly get) there is a big challenge from the Muslim community World.

Nurcholish Madjid, which has high commitment to Islam, throws the idea of "Islam, Yes; Islamic Party, No". This was a reflection of counteracting the emergence of many Islamic parties in 1970s. It also departed from the disappointment of the Islamic parties who did not succeed in building a positive image and sympathy. ${ }^{17}$ In other words, the rejection of the Islamic political party institutions must be understood as a rejection, not of Islam, but a rejection of the use of Islam by those involved in the life of the Islamic party. Political behavior and the use of Islam in turn, would impose the values of the true Islamic teachings. ${ }^{18}$

\footnotetext{
${ }^{15}$ Daud Rasyid, Reformasi Republik Sakit: Peluang dan Tantangan Penerapan Syariat Islam Pasca Kejatuhan Soeharto, 83.

${ }^{16}$ Nurcholis Madjid, Islam Doktrin dan Peradaban, sebuah Telaah Kritis tentang Masalah Keimanan, Kemanusiaan dan Kemoderenan (Jakarta: Paramadina, 1992), Cet. Ke-8, 204.

${ }^{17}$ Nurcholis Madjid, Islam, Kemoderenan dan Keindonesiaan, 205.

${ }^{18}$ That concern will be the emergence of fineness that smells of SARA. Even though the term itself is the terminology, SARA created the regime at that time to beat up political power of Muslims. See Daud Rasyid, Reformasi Republik Sakit: Peluang dan Tantangan Penerapan Syariat Islam Pasca Kejatuhan Soeharto, 72.
} 
However, Nurcholis Madjid's thinking about "Islam, Yes"; Islamic Party, No", gives a message that that Muslims should not establish an Islamic state with Islam as a political vehicle. Jargon is then used by the government as a tool for Islamic political burned. Actually, this idea has been contaminated ${ }^{19}$ by the New Order regime ${ }^{20}$ which is not accommodating to political Islam. This situation also can be seen as a reflection of the desire of the government at the time not because the Indonesian people are very diverse, in terms of tribe, nation and religion. Another idea expressed by Nurcholish Madjid about secularization in the 1970 s affected the freedom of thinking and the emergence of attitudes of openness among Indonesian Muslims which is not to idolize everything in the material world. This has made the Muslim community aware of the nature of value pluralism, tolerance and assessment of the all is not absolute. ${ }^{21}$ Unfortunately, this thought revolves among the high class intellectuals only, not among the lower class people.

Many people reject the idea of secularization espoused by Nurcholis Madjid, including Harun Nasution, a prominent modernist contemporary and Western-education scholar. He does not accept the idea of secularization which has come into the behavior of the separation of the world and the hereafter. Between these two forms there is a clear dividing line. ${ }^{22}$ In this context, what Ibn Taymiyya viewed is interesting to refer. He said that establishing a state is not an order from the shari'a. However, he argued that enforcing Islamic law is a command or obligation. ${ }^{23}$ The power must be run by shura (consultation) and the law should be enforced fairly. A legal maxim that states that, "ma la yatimmu al-wäjib illa bihi, fahuwa wäjib" is relevant to this view. It means that something that can lead another thing obligatory to be done become compulsory. So that, a tool becomes compulsory if without that tool an obligatory thing cannot be perfectly manifested. It further then means in this

\footnotetext{
${ }^{19}$ Another indication is that the government also weakens or hinders the political party. The climax is when all political parties and mass organizations even forced to change each principle to the principles of Pancasila as the sole principle. Ali Murtopo, political henchmen of the new order, through its agency CSIS, trying to burn political hotbed of the most major is the "political Islam". Daud Rasyid, Reformasi Republik Sakit: Peluang dan Tantangan Penerapan Syariat Islam Pasca Kejatuhan Soeharto, 74.

${ }^{20}$ Yasmadi, Modernisasi Pesantren Kritik Nurcholis Madjid Terhadap Pendidikan Islam Tradisional (Jakarta: Ciput at Press, 2002), cet. 1, 30.

${ }^{21}$ Harun Nasution, Islam Rasional (Bandung: Mizan, 1996), cet. ke-4, 193.

${ }^{22}$ The obligation is something that must be executed in Islam. Sharia is the whole of the teachings themselves. In the understanding of the sharia, legal terminology in both al-Qur'ân and contained in the Hadith of the Prophet, contain an appropriate legal norms that have evolved. See Yusril Ihza Mahendra, introduction to, Mengawal Syariah, by MS. Kaban (Jakarta: Pustaka ArRaihan, 2007), v.

${ }^{23}$ MS Kaban, Introduction to Mengawal Syariah (Jakarta: Pustaka Ar-Raihan, 2007), viii. 110 | INDO-ISLAMIKA, Volume 2, Nomor 1, 2012/1433
} 
context that to enforce shari'a, there must be mean, i.e., state (Islamic state). ${ }^{24}$ This thought is not suitable to the reality, due to carry out the commands of God and leave His ban, facing difficulties in the absence of binding rules set by the state. Therefore, islamisation of the state is necessity. When it cannot enforce Islamic laws in the country, then establish an Islamic state and/or make an Islamic state absolutely becomes obligatory to do and if it is not be done surely Allah will reduce the blessings of life, even the punishment of Allah is very surely painful fall.

\section{A. Factors Affecting the Legal Politics}

The concrete interdependence of economy and political Islam can be clearly seen in the idea of Indonesian Muslims' establishing of Islamic banks, which is loaded with political content. At first, the relationship between Muslims and New Order was characterized by suspicion and prejudice. The rulers of the New Order in the 1970's were still suspicious of the idea, as one manifestation of the movement to establish an Islamic state or the realization of the Jakarta Charter. Therefore the government at that period did not support the establishment of these institutions.

Before I go further to the historical success of the establishment of Islamic banking, I shall here discuss factors which influence the establishment of shari'a law, which I categorize it into two prominent factors, i.e., internal and external factors.

\section{Internal Factor}

\section{a. Ideology}

Pancasila, ${ }^{25}$ as the basic philosophy of the Republic of Indonesia guarantees the life of the people and the nation. Article 29 of the 1945 Constitution which concerns freedom of belief and its implementation should be viewed as a strong sign of freedom for the Islamic community to manifest their religious faith. This article has several interpretations. For some Muslims, in achieving the ideals of Islam, formalization is a must with the determination

\footnotetext{
${ }^{24}$ The official reason proposed by the Government about not allowing the establishment of Islamic banks is because of the way of the operation of Islamic banks, which demand more equitable distribution of revenue-sharing system, not in line with prevailing legislation, namely Law no. 14 of 1967, Chapter I Article 1, which does not allow the operation of the bank's interestfree credit. See M. Dawam Rahardjo, "Bank Islam”, dalam Ensiklopedi Islam Tematis (Jakarta: PT. Ichtiar Baru Van Houve, 2002), 399.

${ }^{25}$ Basic philosophy of the state and nation and the state of the Republic of Indonesia comprising the five precepts, namely: 1) Belief in God Almighty, 2) a just and civilized humanity, 3) unity of Indonesia; 4) Democracy, led by the wisdom of wisdom in deliberation and representation, and 5) Social justice for all Indonesian people.
} 
of the provisions of shari'a in the legal provisions (formal legal), and neglect the fact that the formation of Indonesia is based on social contract. ${ }^{26}$ The enactment of the Islamic Banking Law actually is relevant with the State ideology of Indonesia whose majority of its inhabitants conceives Islam and need laws governing religious-based economy.

\section{b. Religion}

In Indonesia, whose inhabitants are predominantly Muslim, the teachings of Qur'an and Sunna serve as guidelines for life (way of life) and daily worship, either vertically or horizontally, Including the basic ideas about the financial system, based on the scheme for results (profit and loss sharing). Islam has introduced its economic system as a solution to the world economy which has been experiencing a business downturn caused by usury.

Islam does not offer a system of interest (interest). Islam invites depositors to participate in the business. The depositors can have a share of profits (banks) in accordance with a predetermined ratio. Thus, it establish a partnership between the banks and depositors on one hand, and between the bank and customer savings depositors on the other hand, who manage investments in various productive enterprises. ${ }^{27}$

In the era of economic development the role of banking institutions is very important and decisive. Banks based on Islamic principles are expected to have a considerable effect on the establishment of an Islamic economic system which has became the desire of every Islamic country or countries where the majority of the population are Muslims.

\section{c. Political Power of the New Order}

Facing of condemnation and criticism of various policies in the operation, the Chairman of the New Order, Soeharto, built alliances together with political parties, hoping to mobilize popular support for him. There are two political parties that provided support to this; Nahdhatul Ulama (NU) and Indonesian National Party (PNI). NU was prevalent among students in rural areas and among Muslim entrepreneurs who form the majority of indigenous

\footnotetext{
${ }^{26}$ Mervyn K. Lewis and Latifa M. Algaoud, Islamic Banking, translated by Burhan Subrata Perbankan Syariah Prinsip, Praktek dan Prospek (Jakarta : PT. Serambi Ilmu Semesta, 2007), Cet. $1,9-10$

${ }^{27}$ Santri and abangan are sociological terms which are already familiar among the Muslims of Java. Culturally, santri is used to describe a group of devout Muslims in the run religion. In contrary, abangan is the term for which no devout Muslim religion in running, especially in the areas of sociology Java ubudiyah. Each group can make their own community sociological association boundaries exclusively. Each has a culture and patterns of social relationships on their own, so it seems exclusive. Exposure famous for sharing this dichotomy. See Clifford Geertz, The Religion of Java (London: The Free Press of Glencoe, 1960), 6.
}

112 | INDO-IsLAMIKA, Volume 2, Nomor 1, 2012/1433 
Indonesian business community. NU also possessed a relatively united leadership. Alternatively, PNI was popular among abangan (community groups who embraced Islam, but did not practice Islam as a whole) and most important, ${ }^{28}$ among the civil service and state bureaucracy. In simplifying the number of parties, the government (in this case the majority members of parliament were Golongan Karya (Golkar), deputy armed forces and regional representatives) proposed to align the flow of mysticism with the existing five religions of Indonesia, and with easy approval. Marginalizing the involvement of Muslims took place with the enactment of a single principle ${ }^{29}$ : Socialization Pancasila with the P4 program (appreciation and Implementing Guidelines Pancasila) intended to avoid the conflict of ideology.

Besides, strong reaction against the government's policy was still visible, such as the case of the Tanjung Priok incident on September 12, 1984. However, Muslims realized that confrontational resistance would not succeed. Accordingly, the young intellectuals, such as Bachtiar Effendi and Nurcholis Majid, reoriented the political meaning of Islam which had been elaborated in shades of legality and formality. The new politic orientation led to a more substantive and integrative political view. The new approach meant that more emphasis was applied to the aspects of the content of Islamic values as a source of inspiration for political power and attitude in accepting and adjusting to each other between Muslims and the state. ${ }^{30}$

In the period 1982-1985, a good relationship between Islam and the state began to materialize, even though it had not yet reached an ideal stag. The Third National Conference of Golkar in October 1983 marked the beginning of a new era of the elite political role of Islam in the body of the New Order state party. Akbar Tanjung, the Chairman of HMI (Himpunan Mahasiswa Islam) competed with Sarwono Kusuma atmadja, from the "Group of Bandung" student activists which had a patronage relationship with General LB Moerdani. Both of them fought for the position as Golkar SecretaryGeneral. Akbar, who had a HMI background course, had a more Islamic vision than Sarwono, who was more socialist-oriented. Although Akbar was defeated in this battle, it still gave new meaning to the development of Golkar in the future. In the first two decades of the New Order Golkar controlled abangan (community groups who embraced Islam, but did not practice Islam as a whole)

\footnotetext{
${ }^{28}$ After the application of this single principle, all political magnitude (party) and all social organizations must make it as a basis for party ideology or organization. See Francois Raillon, "The New Order", 204.

${ }^{29}$ Jamhari, "Islam di Indonesia” dalam Ensiklopedi Tematis Dunia Islam (Jakarta: PT Ichtiar Baru van Hoeve, 2002), 360.

${ }^{30}$ Community groups who embraced Islam, but not practicing Islam as a whole.
} 
who were more anti-Islamic. However, the appearance of Akbar as a secretary general candidate gave leaders of Islamic movements greater hopes to be able to play a more influential role in the body of Golkar in the next period. ${ }^{31}$

\section{d. Economic}

Prolonged global recession has resulted in a decline of export revenues and foreign investment flows at the same time. While oil exports and foreign investment, together with foreign aid by the former Minister of Finances, Mr. Sumarlin, are three sources of "windfall," in the meantime, there are new challenges against it. In addition, a number of the previous problems remain unsolved, including, in particular, the unemployed working age population, whose number is estimated to grow each year, approximately 2 million people. In facing these challenges, the government has conducted a series of economic policies by introducing savings and spending reductions, tax reform, reorganization of customs, fiscal reform, monetary, and public administration, with the spirit of "deregulation and bureaucratization. ${ }^{32}$

In this context, it was hoped the presence of Islamic banks such as Bank Muamalat Indonesia (BMI) could help answer the economic problems faced by the government. It must be mentioned that this prolonged economic crisis, due to the scarcity of sources of funding post-oil boom of the new order also encouraged countries to use financial assistance and credit facilities from the Islamic Development Bank (IDB). IDB was established by the Organization of Islamic Conference (OIC) on 23 April 1975, and was aimed at promoting economic growth and improving the social welfare of its 44 member countries, including Indonesia. IDB is intended to function as well as the World Bank, International Monetary Fund and Asian Development Bank (ADB) in attempting to achieve its objectives; encourage economic growth in Muslim countries, raise bank stock purchase dues of its member countries and then provide assistance or facilities to its members. Facilities or assistance provided varies widely, but generally in the form of equity participation, loans are not binding and do not interest, either private or government. ${ }^{33}$

\section{e. Social}

According to Bachtiar Effendy, there are two main reasons why the New Order recruited Muslims. Firstly, from a sociological angle the opening of

\footnotetext{
${ }^{31}$ Leo Suryadinata, Golkar dan Militer (Jakarta: LP3ES, 1992), 21.

${ }^{32}$ Mohtar Mas'oed, Struktur Ekonomi dan Politik Orde Baru, (Jakarta: LP3ES, 1989), 214.

${ }^{33}$ IDB relations and BAPINDO, Info bank, No. 53/1984, 16-17.
} 
access to education and economic activity provided many opportunities for scholars studying abroad. Their return from their studies was accompanied by social mobility which made the value of Muslim's bargaining power stronger, so they needed to be accommodated into the structure of the country. Secondly, improving the quality of Muslim education and the ability to spread the ideas of Islamic scholars in Islamic thought has meant that the government was not likely to ignore their existence, especially since these thoughts in some respects were in accordance with the direction and policies developed by the New Order. ${ }^{34}$

Furthermore, the New Order government shaped its accommodation of Islam in four other areas; structural, legislative, infrastructural and cultural accommodation. Structurally, this accommodation meant the recruitment of Muslim leaders onto executive agencies (bureaucracy) and legislative institutions of the state. This accommodation was clearly visible when President Soeharto agreed to the establishment of ICMI (Association of Indonesian Muslim Intellectuals) in 1990. The legislative accommodation was associated with the issuance of laws or regulations relating to Islam as an independent and legitimate rule. Among this policy of accommodation were ratification of the National Education Act of 1989, the enactment of laws on religious courts, the permissibility of wearing the jilbab (a long heads craft or loose shirt to the knee) in 1991 and legislation relating to Islamic banking in Indonesia in 1992.

\section{f. Culture}

It is known that the Indonesian nation has a culture of living together and cooperativeness. Tthere are number of evidences of this, such as the idea of gotong royong. This is also clear in article 33, paragraph 4 of the Constitution which reads: "The national economy maintained by the principle of economic democracy with the principles of togetherness, equitable efficiency, sustainability, environmental friendliness, independence, and balancing economic progress and national unity." The most appropriate economic institution to translate the above is Islamic Banking, due to a number of reasons; (1) Shari'a banking is in accordance with the aspirations of society and is very appropriate for the Indonesian people to run most of the micro business, small and medium enterprises (economic democracy), (2) its priority is to progress together rather than have individual advancement (principle of togetherness), (3) It is very fitting solution for small communities so that they

\footnotetext{
${ }^{34}$ Bachtiar Effendy, Islam dan Negara: Transformasi Pemikiran dan Praktek Politik Islam di Indonesia (Jakarta: Paramadina, 1998), 37-38.
} 
can enjoy banking services and to empower themselves (principle of fairness and independence), (4) it rejects to be supported or partnered with entrepreneurs or companies involved in environmental damage (the principle of sustainability and the environment), (5) it combines worldly demands with the demands of the next (principle of balance), and (6) it is strong in maint aining the progress of the real sector, which is very suitable with a national economy based on natural and human resources (Principle of national economic unity and cooperativeness). ${ }^{35}$

In line with Indonesia's national development objectives to achieve the creation of a just and prosperous society based on economic democracy, Indonesia needs to develop an economic system based on values of justice, solidarity, equity, and usefulness. Islamic Banking is the only one, and the most appropriate institution to translate the national development objectives at the top in the real life.

\section{External Factors}

The establishment of the IDB, then triggered the establishment of Islamic banks worldwide, including in the European region. In the Middle East, Islamic banks began popping up in the second half of the 1970's, for example Dubai Islamic Bank (1975) and Kuwait Finance House (1977). In Iran, the Islamisation of the banking system was carried out nationally after the founding of the Islamic Republic of Iran. In Southeast Asia, a banking development milestone occurred in the early part of the '80s, with the establishment of Bank Islam Malaysia Berhad (BIMB) in 1983: by the year 2000, BIMB had developed 70 branches throughout Malaysia. The BIMB's success was mainly supported by cooperation with a number of economic institutions and saving for pilgrimage programs. Its success led to the birth of Islamic banks which is similar to what happened in Indonesia. ${ }^{36}$

In Indonesia, the first Islamic bank, Bank Muamalat Indonesia (BMI) was only established in 1991, whereas the thinking about Islamic banks had been happening since the 1970's. The obstacle to its establishment was a political factor. The establishment of Islamic banks was considered as part of the ideals of establishing an Islamic state. The establishment of BMI was also as a result of political factors, namely the birth of ICMI and then the embracement the Indonesian Ulama Council (MUI). Previously, they had not approved the establishment of Islamic banks because they are based on laws that are not

\footnotetext{
${ }^{35}$ Zubairi Hasan, Undang-Undang Perbankan Syariah, Titik Temu Hukum Islam dan Hukum Nasional (Jakarta: Rajawali Press, 2009), 11-12.

${ }^{36}$ A. Riawan Amin, Menata Perbankan syariah di Indonesia, 87.

116 | INDO-ISLAMIKA, Volume 2, Nomor 1, 2012/1433
} 
familiar with the banking system without interest. But, because of the attitude of the government, especially after the approval of President Soeharto at the time, then the BMI could be established. President Soeharto himself even took part to raise capital initially and the role of government in the capital raising was very important, including asking the state to participate and become shareholders. $^{37}$

\section{a. External Politics}

The driving factor behind the establishment of Islamic banking is the fact that Muslim countries particularly and secular states generally, have opened up and operated bank profit-sharing principles. In regards to that, Indonesia, as the first largest Muslim country in the world, was intrigued to realize that Indonesia has received a great amount of assistance from Islamic banks in the world. After the establishment of Islamic banks in Indonesia, the IDB provided assistance on technical skills to prospective managers and sponsored studies and seminars necessary for the establishment of Islamic bank in Indonesia. Special assistance was provided by the IDB as stipulated in the articles of association, article 2, paragraph (xi) in clause 103 reads. IDB has provided technical assistance, either in the form of economic organization of seminars and Islamic banking around the world or in the form of financing to bank personnel who study in Islamic banking and Islamic banking experts that the new stand. ${ }^{38}$ Bank Muamalat Indonesia (BMI), also sponsored studies and seminars required for the establishment of Islamic banks in Indonesia.

\section{b. Economic}

The Islamic world community wants to be liberated from a the bondage that gripped the capitalist system. The international financial system has faced barrage of crises over the last two decades, which has brought about a new awareness of the need for reforming the financial-system architecture. This situation has also provided fresh air for the development of Islamic financial systems. An Islamic financial system is expected to inject discipline as well as pushing for the fulfillment of prudential regulation and supervision in the financial industry. These phenomena have encouraged Islamic banks in large numbers to pop up all over the world throughout the last 30 years. ${ }^{39}$

Factors of economic relations between countries, especially the 1974 and 1979 oil crises, lead to financial strength in the form of petro-dollars to

\footnotetext{
${ }^{37}$ A. Riawan Amin, Menata Perbankan syariah di Indonesia, 88.

${ }^{38}$ Karnaen Perwata Atmaja dan Syafii Antonio, Apa dan Bagaimana Bank Islam, 67.

${ }^{39} \mathrm{M}$. Umer Chapra dan Habib Ahmed, Corporate Governance in Islamic Financial Institution (Jeddah: Ocasional Paper IDB, 2002), 1.
} 
countries in the Middle East and North Africa and included Indonesia, Malaysia and Brunei in Southeast Asia. Seeing the symptoms, arising the thought of turning petro-dollar funding through financial institutions of Shari'a. ${ }^{40}$ Before the founding of BMI, Indonesia has long been utilizing assistance from the IDB.

\section{B. The Formation of Islamic Banking Law}

Now I am turning to the discussion of the enactment of Islamic banking law. I will focus on stages of the law-making mechanism which consist of four phases.

\section{a. Submission and Review Bill ${ }^{41}$}

Discussion of the Bill is derived from the President and Parliament. Article 5, paragraph 1 of the Act of 1945 changes the article that entitles the President to propose draft laws. The changes are not stated explicitly in the formulation of the constitutions of 1945. The right to bring this bill arises from the authority of Parliament as the holder of power established by law. Since the Parliament is a representative institution, of course, the power to make laws is also reflected the rights held by members of Parliament. ${ }^{42}$ For that, the Article 21 of the Act of 1945 is the results of changes that entitle lawmakers to propose the bill. As regulated, a proposed bill that comes from the members should be discussed by the Parliament for approval as a draft. Discussion of a bill between the President and the Parliament is relevant to the constitutional provisions as stated in article 20 paragraphs (2). This is in contrast with conditions before changes where the requirement of discussions with the terms of constitutuality of law was not needed. Article 20 paragraph (2) of the 1945 constitution before the amendemnet states that "if a bill is not approved by the board of the representatives, the draft was not to be brought forward again in the House of Representatives trial period"

\section{b. Joint Agreement on the draft proposal stage}

A forum to discuss the draft proposal made by the President and Parliament is very important and even become a statutory constitutional

\footnotetext{
${ }^{40}$ M. Dawam Rahardjo, XVI.

${ }^{41}$ Next term writer Bill Short Bill.

${ }^{42}$ The difference between the legislation and regulations in this regard is that the legislative activities undertaken by representative institutions of the people or at least involve the role of the elected people's representative bodies through elections, while the regulation is a regulation by the executive that runs the product of legislation and get the delegation of authority to regulate (regulation) that the relevant legislation of the product. Jimly Asshiddiqie, Hukum Acara Pengujian Undang-Undang (Jakarta: Konspres, 2006), cet, ke-1, 27.
}

118 | INDO-IsLAMIKA, Volume 2, Nomor 1, 2012/1433 
requirement. The next requirement is that in the discussions joint agreement must be reached. Approval should be concerned with two things: (i) the formal aspect and (ii) the substance of the interrelated aspects. From the formal aspect of these discussions a draft agreement on issues should be produced that has been agreed upon and to which both parties sign consent.

From the aspect of substance, to accommodate the things, it is stated in the agreement text which is the substance of the discussion together. In the case of joint discussions, if there has not been, or cannot be, agreement on the proposed bill, then, agreement or approval of the manuscript has not been or cannot be formulated. This text is very important because the process of making constitutional law is associated with the mutual consent of the President and the Parliament that has been stated in the text as reflected in this phase. If it turns out that the President and Parliament fail to reach mutual agreement on the bill of material within a period of trial time, then the provisions of Article 20 paragraph (3) prohibits the bill from being filed back in the House of Representatives hearing during that period.

\section{c. Ratification Bill to Become Islamic Banking Act}

Constitutional processes required for making a legal bill into law are found in the legal arrangements contained in Article 20 paragraph (4) and subsection (5) of the 1945 Constitution after (amendement). Article 20 paragraph (4) and subsection (5) of the 1945 Constitution after the change. Article 20 paragraph (4) states "The President passes a bill that has been mutually agreed to become law." Given this provision, the changing of a bill into law is because of an act of the President to pass legislation that has been agreed with the House. On the other hand, the 1945 Constitution provides an alternative when a bill that has been agreed by the President and Parliament to change their legal standing to become a law. It is stipulated in Article 20 paragraph (5), which states, "If this bill mutually agreed upon is not authorized by the President within thirty days since the bill's approval, the bill is legitimate to mandatory laws and enacted."

The House of Representatives (DPR) passed the Draft Law of Islamic Banking into the Act in a plenary session led by the chairman of the House, Agung Laksono at the Plenary Meeting room, Building Nusantara II, Tuesday, June 17, 2008. Views of some factions on Islamic banking can contribute to the national economy. ${ }^{43}$ There are a lot of supports provided by a number of people

\footnotetext{
${ }^{43}$ See www.dpr.go.id, dated June 18, 2008, 1.
} 
who are not only representatives of Islamic parties but also of non Islamicnational parties. ${ }^{44}$

A spokesman F. PAN, Nurul Falah expressed her opinion that "the current Islamic banking (Act/Law) has provided a significant contribution in the effort to cultivate an economic system that is based on the value of justice. In addition, she considered that the existence of Islamic banking provides a significant contribution also in mobilizing various sectors of the Indonesian economy, especially the medium business sector, small and micro enterprises."

Meanwhile, a spokesman for the F-NAP, Arsa Suthisna considered that 'Islamic banking is still young, of course, still has a weakness, especially in the limited quality and quantity of human resources. For that, Islamic banking must prepare qualified persons who have integrity, morality and high commitment". He also called for the socialization of Islamic banking, as he saw that society has very low understanding of the products of Islamic banks and the their differences with those of conventional banks.

Tukijo, a spokesman for the F-PDIP, judged that Islamic banking has increased rapidly and has received a positive response from the banking services industry. For that, Islamic banking should not be standing in an exclusive position and limiting the parties that would be associated with the use of Islamic banking services, but it must be open to the interests of all levels of society. F-PG, through its spokesman, Harry Azhar Aziz explained that:

"The orientation in Islamic banking Act is on the stability of the system by adopting 25-Based Core Principles for Effective Banking Supervision, especially related to the licensing, prudential, liability risk management, coaching and supervision, and networking the security system of Islamic banking. This fraction also assesses the presence of these principles. The Islamic banking bill will have aspects of shari'a compliance, consumer protection, comfort and certainty of investment climate and stability of the banking business as a whole".

According to F-PPP's spokesman, Sofyan Usman, the existence of the Islamic Banking Act is extremely urgent and long-awaited for in various circles, for Islamic banking in Indonesia has been in operation long enough and experienced rapid growth. This emphasizes the interest of various circles in the Islamic banking services that must be answered by giving more open and developed space.

${ }^{44}$ Data was obtained from the recording Mr. Sugiono (staff Faction of the National Awakening) the session of Parliament, June 20 th, 2008

120 | INDO-IsLAMIKA, Volume 2, Nomor 1, 2012/1433 
Tata Zainul Muttaqin of F-PD stated that Islamic banking is one form to restore the national economy through investment in the world of Islamic banking, especially investment from overseas, especially the countries in the Middle East. Therefore, it needs to arrange for a more detailed and more clearly about Islamic banking. ${ }^{45}$

F-FBR spokesperson, Zainul Abidin, explained that anyone can take advantage of financial services of Islamic banks. When the monetary crisis hit Indonesia in mid-1997, shari'a has been consistently giving the benefits to many groups. It became one of the facts that Islamic banks in Indonesia contributed significantly to the resilience and growth of the country's economy.

Meanwhile, F-PKS through its spokesman Mustafa Kamal hoped that" the implementation of Islamic banking should be followed by greater partisanship and real in terms of distribution of funds for small and medium enterprises as well as easy access to funds for SMMEs: so as to move the real sector and have greater benefits for the creation of prosperity and welfare of the people."More simply, the views of the F-BPD expressly agreed the bill was enacted into law.

However, not all agreed that Fraction shari'a banking law should be enacted into law. One of the 10 factions in the House, F-Shari' a Banking PDS, rejected the bill being passed on the grounds that shari'a banking is not in accordance with Indonesia's basic law of the Pancasila and UUD 1045. Fraction through its spokesman, Retna Rosmanita Situmorang, said that "...information in some countries he knew, it is evident that Islamic banking products are not in the form of the Act, only a derivative of the banking laws that exist, not in special law."46

From the Government side, the Minister of Religious Affairs, Maftuh Basyuni, stated that he "...hopes in the adoption of Islamic Banking Act to encourage the domestic banking industry to grow and develop better. We hope to quickly set up the rules of implementation of this Act by Bank Indonesia."

\section{d. Phases of Enactment}

Provisions regarding the promulgation of the Law in the 1945 Constitution are mentioned in Article 20 paragraph (5) which regulates that the bill is not authorized by the President to declare "enacted mandatory." This case was certainly not intended that the mandatory enacted only bill that became law because according to Article 20 paragraph (5) the bill that became law did so because the President was obliged to enactment. Section 22A of the Constitution states that "Further provisions concerning the procedures for the

\footnotetext{
${ }^{45}$ See www.dpr.go.id, dated June 18, 2008, 2 (Accessed Date February 21, 2010).

${ }^{46}$ See www.dpr.go.id, dated June 18, 2008, 3. , 2 (Accessed Date February 21, 2010)
} 
establishment of laws regulated by law." Thus, the enactment of ordinances can be set in the legislation implementing the Article 22A.

The legal basis is the fourth stage of the above, stipulated in Law No. 10 of 2004 on the Establishment of Laws. A draft bill should contain in it: (1) substantive law contained in the formulation of regulations that have been agreed between the President and Parliament. It is necessary to be authentic evidence about things that have been approved. (2) Evidence of the House of Representatives and the President of agreed with the substance that has a law by affixing signature of the President and Speaker of the House as an institution. (3) Momentum or the time when agreement was reached and then signed by the President and chairman of the House of Representatives.

\section{Conclusion}

Religious teachings, which can provide a foundation of universal values and morals, are a fundamental requirement for the people of Indonesia which is undergoing the process of modernization in various areas; social, political, economic and legal culture.

Attempts by a number of the parties to try to end the meeting and if possible even seal the reform of Islamic law into national law has always failed. They, who opposed the implementation of Islamic law, had no choice than to accept shari' a banking law whose regulations are taken from the Koran and alHadith and see it accommodate into national law in the form of legislation.

While, the state was before hostile to Islam and its implementation, Islamic banks are experiencing significant progress, and even many conventional banks have opened Islamic divisions. When considering the various quite rapid changes from the development of an Islamic economic system, that is manifested in the form of Islamic banking, to the accommodation of banking regulations, there arises a big question: Why did it all happen so quickly? With the assumption that between economics and politics there occurred 'interdependency' (a very close relationship). Another question then came up of what political event that let it all happens. The answer seems to be that the establishment of shari'a law thanked to the values of religious faith, ideological, political, economic, social and cultural rights.

\section{Bibliography}

Amin, A. Riawan. Menata Perbankan Syariah di Indonesia. Jakarta: UIN Press, 2009.

Asshiddiqie, Jimly. Hukum Acara Pengujian Undang-Undang. Jakarta: Konspres, 2006. 
Atmaja, Karnaen Perwata dan Syafii Antoni. Apa dan Bagaimana Bank Islam. Yogyakarta: Dana Bhakti Wakaf, 1992.

Bisri, Cik Hasan Bisri. "Transformasi Hukum Islam ke Dalam Sistem Hukum Nasional.” Jurnal Mimbar Hukum No. 56 Thn XIII. Jakarta: Al-Hikmah, 2002.

Chapra, M. Umer dan Habib Ahmed. Corporate Governance in Islamic Financial Institution. Jeddah: Ocasional Paper IDB, 2002.

Effendy, Bachtiar. Islam dan Negara: Transformasi Pemikiran dan Praktek Politik Islam di Indonesia. Jakarta: Paramadina, 1998.

Friedman, W. Legal Theory. 3rd Edition. London: Stevens and Sons Ltd. 1953.

Geertz, Clifford. The Religion of Java. London: The Free Press of Glencoe, 1960.

Hasan, Zubairi. Undang-Undang Perbankan Syariah, Titik Temu Hukum Islam dan Hukum Nasional. Jakarta: Rajawali Press, 2009.

Ismail, Suny. Sekitar UUPA (Dalam Kitab Agama Dalam Negara Pancasila). Jakarta: Pustaka Antara, 1990.

Jamhari. "Islam di Indonesia", dalam Ensiklopedi Tematis Dunia Islam. Jakarta: Ichtiar Baru van Hoeve, 2002.

Jazuni. Legislation Islamic Law in Indonesia. Bandung: Citra Aditya Bakti, 2005.

Lewis, Mervyn K. and Latifa M. Algaoud. Islamic Banking, translated by Burhan Subrata Perbankan Syariah Prinsip, Praktek dan Prospek. Jakarta: PT. Serambi Ilmu Semesta, 2007.

Madjid, Nurcholis. "Demokrasi dan Demokratisasi di Indonesia”, ed. Elsa Pedi Taher, Demokratisasi Politik, Budaya dan Ekonomi . Jakarta: Paramadina, 1994.

Madjid, Nurcholis. Islam Doktrin dan Peradaban, sebuah Telaah Kritis tentang Masalah Keimanan, Kemanusiaan dan Kemoderenan. Jakarta: Paramadina, 1992.

Kaban, MS. Introduction to Mengawal Syariah. Jakarta: Pustaka Ar-Raihan, 2007.

Mas'oed, Mohtar. Struktur Ekonomi dan Politik Orde Baru. Jakarta: LP3ES, 1989).

MD, Mahfud. "Politics of Human Rights Law in Indonesia" (Inauguration Speech in office Professor, Islamic University of Indonesia. Yogyakarta, September 23, 2000.

Nasution, Harun. Islam Rasional. Bandung: Mizan, 1996.

Rahardjo, M. Dawam. Introduction to Bank Islam translated by Adiwarman Karim, Analisis Fiqih dan Keuangan. Jakarta: PT Raja Grafindo Persada, 2006). 
Rahardjo, M. Dawam. "Bank Islam," dalam Ensiklopedi Islam Tematis. Jakarta: PT. Ichtiar Baru Van Houve, 2002.

Raillon, Francois. "The New Order and Islam, or the Imbroglio of Faith and Politics." Indonesia, Vol 5, (1994).

Rasyid, Daud. Reformasi Republik Sakit: Peluang dan Tantangan Penerapan Syariat Islam Pasca Kejatuhan Soeharto. Bandung: Syaamil, 2006.

Soekanto, Soejono. Pokok-pokok Sosiologi Hukum. Jakarta: Rajawali, 1991.

Suryadinata, Leo. Golkar dan Militer. Jakarta: LP3ES, 1992.

Wahyuni, Sri. "Politik Hukum Islam di Indonesia (Studi terhadap Legislasi Kompilasi Hukum Islam)." Jurnal Mimbar Hukum No. 59 T XIV, alHikmah, (2003).

Yasmadi. Modernisasi Pesantren Kritik Nurcholis Madjid Terhadap Pendidikan Islam Tradisional. Jakarta: Ciputat Press, 2002.

\section{Website}

http://aanaboodzforlife.com/2010/02/sistem-perbankan-syariah www.dpr.go.id. 